\title{
Hormonal Regulation of the Rat Small Intestine: Responsiveness of Villus and Crypt Cells to Insulin during the Suckling Period and Unresponsiveness after Weaning
}

\author{
JEAN-PAUL BUTS, NADINE DE KEYSER, JAROSLAW KOLANOWSKI, AND \\ FRANÇOIS VAN HOOF \\ Laboratory of Pediatric Gastroenterology and Nutrition, Laboratory of Experimental Endocrinology and \\ Laboratory of Biochemistry, Faculty of Medicine, University of Louvain and the International Institute of \\ Cellular and Molecular Pathology, Brussels, Belgium
}

\begin{abstract}
To further document the effect of insulin on intestinal maturation, suckling rats were treated either with exogenous insulin $(12.5 \mathrm{mU} \cdot \mathrm{g}$ body wt, intraperitoneally, twice daily) or with saline from d 8 to 12 postpartum. Sucrase activity in brush border membrane extracts was precociously induced by insulin, whereas the activities of other brush border membrane enzymes (maltase, aminopeptidase, and neutral lactase) were enhanced $(+30$ to $+131 \%, p<0.01$ versus controls). The lysosomal enzyme, $\mathrm{N}$-acetyl- $\beta$-glucosaminidase, which normally declines at weaning was significantly $(p<0.025)$ decreased in both villus $(-51 \%)$ and crypt cells $(-57 \%)$ isolated from the jejunum of insulin-treated rats. The microsomal enzyme, sulfatase $C$, and the cytosolic enzyme, lactate dehydrogenase, were also sensitive to insulin with decreases in activity ranging from -37 to $-63 \%(p<0.05)$ compared to salinetreated control rats. Insulin at doses of 0.5 or $12.5 \mathrm{mU}$ did not influence plasma total corticosterone levels, which were about 9-fold lower in suckling than in 25-d-old weaned rats. In weaned rats (from d 25 to 32 ) insulin treatment $(12.5 \mathrm{mU})$ failed to influence the activity of brush border membrane hydrolases or of lysosomal, microsomal, and cytosolic enzymes. The synthesis rate of mature sucraseisomaltase, measured in weaned rats $(32 \mathrm{~d})$ by the incorporation of ${ }^{14} \mathrm{C}$-leucine into the enzyme precursor protein, was equivalent in both groups. These data demonstrate that the immature enterocyte of the suckling rat is responsive to insulin, whereas the mature enterocyte of the weaned rat is unresponsive. The effect of insulin on the intestinal cell appears not to be mediated via an endogenous stimulation of corticosterone release. (Pediatr Res 27:161164, 1990)
\end{abstract}

\section{Abbreviations}

BBM, brush border membrane

S-I, sucrase-isomaltase

ip, intraperitoneal

During the weaning period (d 14 to 21 ) the rat small intestine undergoes rapid changes in its pattern of enzyme expression.

Received July 11, 1989; accepted September 27, 1989

Correspondence and reprint requests Jean-Paul Buts, M.D., Ph.D., Department of Pediatrics, Cliniques Universitaires St-Luc, 10 Avenue Hippocrate, B-1200 Brussels, Belgium and of the US Public Health Service (NIH DK 9235).

Supported by Grant 5242-01 and 6.242-01/3-4510-89 from the "Fonds de la Recherche Scientifique Médicale" (FRSM), Belgium.
Enzymes that display a high activity during the nursing period, such as neutral lactase and lysosomal hydrolases, will decline at weaning, whereas other enzymes are specifically induced (S-I) or show a marked increase in their activity (maltase, aminopeptidases) $(1,2)$. Although the precise mechanism(s) that initiate these ontogenic changes remain unknown (3), accumulating evidence indicates that intestinal maturation, regarding enzymatic adaptation, is hormonally controlled. The principal candidates are corticosterone $(2,4)$ and thyroxine $(2,5)$.

The possible role of insulin as a regulatory factor in the maturation of villus and crypt cell functions has been stressed by recent experimental data. The exogenous administration of insulin to infant mice (6) and rats (7) induces the precocious appearance of sucrase activity and enhances the activity of other $\mathrm{BBM}$ hydrolases $(6,8)$. However, on the basis of these in vivo experiments, it is still unclear whether these enzyme changes result from a direct action of insulin on the intestinal cell or whether they are mediated indirectly by, for example, corticosterone release, a hormone known to play a key role in the rat intestinal maturation (2). Even the use of in vitro experimental models has led to conflicting results. Arsenault and Menard reported (9) that the addition of insulin to serum-free organ culture explants of suckling mouse jejunum induced sucrase activity and increased certain BBM enzymes, whereas others (10) using organ cultures of suckling rat small intestine failed to find any effect of the hormone on disaccharidases.

The objectives of our study were to determine whether the exogenous administration of insulin to suckling rats could influence the endogenous production of corticosterone and to further document the effect of insulin on villus and crypt cells from suckling and weaned rats by assessing the response of BBM, cytosolic, lysosomal, and microsomal enzymes to exogenous administration of the hormone.

\section{MATERIALS AND METHODS}

Animals. Wistar rats, housed in opaque polystyrene cages in an air-conditioned room at $22 \pm 1^{\circ} \mathrm{C}$ with a 12-h light-dark cycle were used throughout this study. The day of birth was considered as day 0 . During the nursing period, suckling pups remained with their mother from day 0 (eight rats per litter) and had free access to the breast. For experiments on weaned animals, the pups were separated from their mother on $\mathrm{d} 18$ and weaned onto a standard chow diet (N 103, UAR, Villemoisson-sur-Orge, France).

Insulin treatments. To assess the influence of insulin on the endogenous production of corticosterone, an injection of insulin Actrapid MC (SA Novo Industries, Brussels, Belgium) was given 
twice daily (every $12 \mathrm{~h}$ ) to two groups of 7-d-old rats $(n=$ eight per group) at 0.5 or $12.5 \mathrm{mU} \cdot \mathrm{g}^{-1}$ body wt per dose. The hormone was given from d 7 until d 11 postpartum. On the day of the experiment, blood was taken for corticosterone assay $3 \mathrm{~h}$ after the last injection of insulin. This timing was chosen because in our experimental model the hypoglycemic reaction peaks $2 \mathrm{~h}$ after the injection of insulin (19), and because the potential stimulation of endogenous corticosterone production occurs $1 \mathrm{~h}$ after the nadir (26). A control group of rats $(n=8)$ was injected with equivalent volumes of $0.9 \%$ saline following the same schedule.

To document the effects of insulin on the expression of BBM and intracellular enzymes during the suckling period, a group of suckling pups $(n=6)$ received twice daily an ip injection of insulin ( $12.5 \mathrm{mU} \cdot \mathrm{g}^{-1}$ body wt) from $\mathrm{d} 8$ to 12 postpartum. A second group of weaned rats $(n=6)$ received every $12 \mathrm{~h}$ an ip injection of the hormone at the same dose from d 25 to 32 postpartum. The respective control groups of rats were injected with equivalent volumes of $0.9 \%$ saline following the same schedule.

Preparation of tissues. On the day of the experiment, the animals were killed by decapitation and bled. The entire small intestine was removed, trimmed of fat and mesentery, and rinsed in ice-cold saline. To collect epithelial cells from the villus tip to the crypt base, we used Weiser's procedure (11) modified by Raul et al. (12). Briefly, rat jejunal segments $(10 \mathrm{~cm}$ from the pylorus) were removed, everted, and submitted to successive incubations of $10 \mathrm{~min}$ at $37^{\circ} \mathrm{C}$ in $\mathrm{PBS}(\mathrm{pH}=7.4$ ) containing 1.5 $\mathrm{mM}$ dithiothreitol (no $\mathrm{Ca}^{2+}$ or $\mathrm{Mg}^{2+}$ ) under agitation at $170 \mathrm{rpm}$ in a waterbath shaker. By successive incubations, sequential fractions of epithelial cells were obtained. The released cells were collected as described (14), washed twice, and villus and crypt cell fractions were pooled separately (villus cells: fractions $1-5$, crypt cells: fractions 5-10). Thereafter, the cells were homogenized in $50 \mathrm{mM}$ mannitol, $2 \mathrm{mM}$ Tris, $\mathrm{pH}=7.4$. Homogenates were centrifuged at $1400 \times g$ for 10 min to remove cellular debris, sonicated (Branson sonifier B-12), and stored in liquid nitrogen until use.

$\mathrm{BBM}$ were isolated and purified using $\mathrm{CaCl}_{2}$ precipitation (13). Preliminary assays revealed that sucrase specific activity was 20 times higher in the BBM fraction $\left(\mathrm{P}_{2}\right)$ than in the crude homogenate.

Incorporation of $\left[{ }^{14} C\right]+$ leucine into $B B M S-I$. Weaned rats $(32$ $\mathrm{d}$ of age) treated with insulin $(n=6)$ or saline $(n=6)$ were given ip $1.5 \mu \mathrm{Ci} / \mathrm{g}$ body wt $\left[{ }^{14} \mathrm{C}\right]$ leucine $\left(335 \mathrm{mCi} / \mathrm{mM} \mathrm{L-}\left[{ }^{14} \mathrm{C}(U)\right]\right.$ leucine, New England Nuclear, Boston, MA) exactly 60 min after the last injection of insulin and $120 \mathrm{~min}$ before they were killed.

The incorporation rate of S-I into the BBM was estimated by the amount of $\left[{ }^{14} \mathrm{C}\right]$ leucine incorporated into $S$-I protein after quantitative immunoprecipitation of the enzyme solubilized from the BBM by $0.5 \%$ Triton X-100 in PBS (v/v) as described (14).

In brief, $0.5-\mathrm{mL}$ aliquots of $0.5 \%$ Triton X-100 BBM supernatants were mixed with $1.5 \mathrm{~mL}$ of a specific polyclonal rabbit antiserum whose preparation and specificity for rat S-I have been described (14). Each immunoprecipitation was performed in duplicate with a blank, using normal rabbit serum instead of the specific antibody. After standing in the cold $\left(-4^{\circ} \mathrm{C}\right)$ for $6 \mathrm{~d}$, the $\mathrm{Ag}$-antibody mixtures were centrifuged at $10000 \times g$ for $10 \mathrm{~min}$. Virtually no S-I activity was detected in the supernatant. The pellets were washed twice with PBS $(\mathrm{pH}=7.0)$, solubilized in $0.1 \mathrm{~N} \mathrm{NaOH}$, and transferred to vials for counting. Aliquots of supernatant and pellet were taken for protein determination and for estimation of ${ }^{14} \mathrm{C}$ radioactivity in a Beckman liquid scintillation spectrometer (Beckman Instruments, Inc., Fullerton, CA), using Aqualuma as vehicle. Radioactivity found in the blanks was subtracted from the radioactivity found in the immunoprecipitates.

Control studies were performed to assess the specificity of the immunoprecipitate using separation by electrophoresis on 5$15 \%$ gradient polyacrylamide gels containing $0.1 \%$ SDS. After staining of protein in the gel using Coomassie blue, the immunoprecipitates were resolved into lines corresponding only to the subunits (S and I) of the S-I complex.

Biochemical determinations. Plasma corticosterone was measured by a specific protein-binding assay (15) on specimens of blood collected from 25 suckling pups $(11 \mathrm{~d}$ old $)$ treated either with insulin or with $0.9 \%$ saline. The animals were rapidly killed by decapitation, taking care to minimize handling and other disturbances that stimulate corticosterone release (16). Blood was immediately collected in heparinized tubes. Plasma was separated by centrifugation and frozen at $-20^{\circ} \mathrm{C}$ until assayed. Sucrase, neutral lactase, and maltase activities were assayed by the method of Messer and Dahlqvist (17). The lactase assay mixture contained $p$-chloromercuribenzoate to inhibit any residual lysosomal acid $\beta$-galactosidase activity. Activities were expressed as $\mu \mathrm{mol}$ of substrate hydrolyzed per min/g protein.

Aminopeptidase was determined by the method of Maroux et al. (18) using L-alanine- $p$-nitroanilide as substrate. One U equals $1 \mu \mathrm{mol}$ of $p$-nitroanilide formed per min and per g protein. $\mathrm{N}$ acetyl- $\beta$-D-glucosaminidase and sulfatase $C$ were assayed using 4-methylumbelliferyl derivates as substrates, following methods described by Van Hoof and Hers (20). For microsomal sulfatase $\mathrm{C}$, the specificity of the reaction is based on the inhibition of the lysosomal sulfatases $\mathrm{A}$ and $\mathrm{B}$ in the homogenate by the successive addition of barium acetate $(0.01 \mathrm{M})$ and $\mathrm{Na}_{2} \mathrm{SO}_{4}(0.05 \mathrm{M})$. The reaction is optimal at $\mathrm{pH}=7.2$ in the presence of imidazole $(0.1$ M) as activator. Lactate dehydrogenase was assayed by the method of Vassault (21). One $U$ equals $1 \mu \mathrm{mol}$ of substrate hydrolyzed per min and per g protein. Protein content in isolated villus and crypt cells and in BBM was determined by the method of Lowry et al. (19).

Calculations and statistics. All results are given as mean $\pm \mathrm{SD}$. Differences between means were tested for statistical significance using Student's unpaired $t$ test and by ANOVA. Differences were considered significant for $p<0.05$.

\section{RESULTS}

All animals treated with either insulin or saline remained healthy and the hormonal treatments did not affect body gain. As depicted in Figure 1, plasma corticosterone in 11-d-old rats did not change in response to saline or insulin treatment, whatever the dose given. In 25-d-old rats, plasma corticosterone was 9 -fold higher.

The changes in the specific activities of sulfatase $\mathrm{C}, \mathrm{N}$-acetyl$\beta$-glucosaminidase, and lactate dehydrogenase assessed in villus and crypt cells of insulin-treated rats $(12.5 \mathrm{mU})$ and of salinetreated control animals are detailed in Table 1.

Insulin induced significant decreases in these enzyme activities, ranging from -51 to $-63 \%$ in villus cells and from $-37 \%$ to $-58 \%$ in crypt cells. $\mathrm{N}$-acetyl- $\beta$-glucosaminidase, as other lysosomal hydrolases, exhibited a high activity during the rat neonatal and suckling period followed by a marked decrease at weaning (22). Sulfatase C, a microsomal enzyme, and lactate dehydrogenase, a cytosolic enzyme, were also sensitive to the administration of exogenous insulin during the suckling period. In response to insulin treatment $(12.5 \mathrm{mU})$ sucrase activity was precociously induced in sucklings, whereas maltase, neutral lactase, and aminopeptidase activities were prematurely enhanced by $+131,+30$, and +40 , respectively (Table 2 ).

The concentration of protein in the BBM extracts was equivalent in insulin- and saline-treated rats, indicating that the changes in enzyme sp act were not due to a change in BBM protein concentration.

In weaned rats treated between d 25 and 32 postpartum, insulin failed to enhance the sp act of neutral lactase, sucrase, maltase, or aminopeptidase (Table 3). Compared to saline con- 
trols, the variation in BBM enzyme activities was not significant $(-15$ to $+12 \%$ versus controls).

To document a possible effect of insulin on the synthesis of BBM enzymes in weaned rats, we measured S-I synthesis rate by the incorporation of ${ }^{14} \mathrm{C}$-leucine into the enzyme protein precursor, followed by immunoprecipitation of mature S-I from the $\mathrm{BBM}$. The data are detailed in Table 4 . The ratio of S-I protein immunoprecipitated from the BBM/total BBM proteins was equivalent in insulin-treated rats and controls. Furthermore, the ratio of ${ }^{14} \mathrm{C}$-leucine incorporated after $120 \mathrm{~min}$ into mature $\mathrm{S}-\mathrm{I} /$

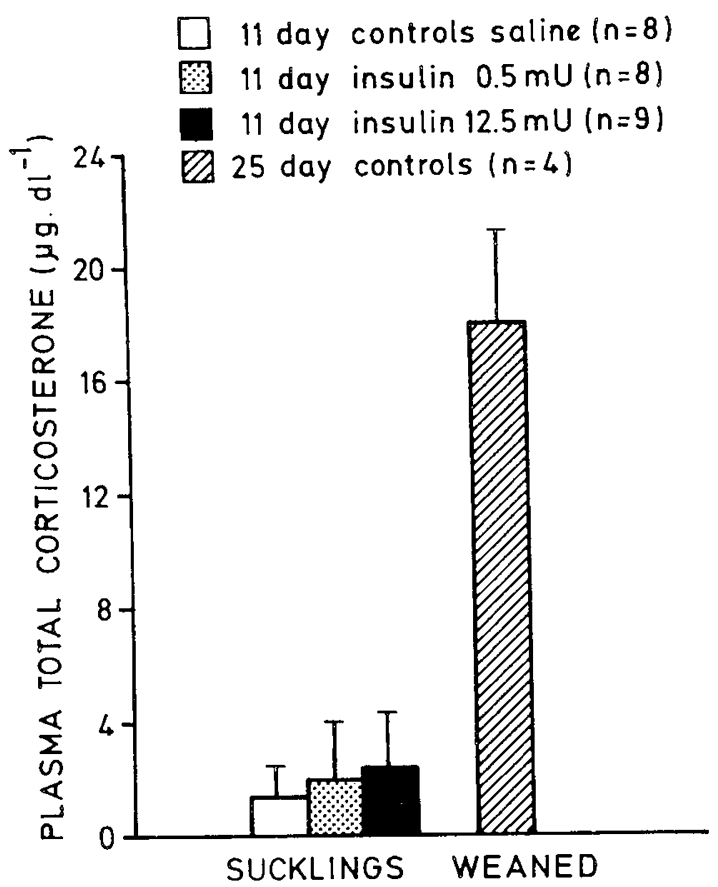

Fig. 1. Changes in plasma total corticosterone in suckling rats treated from $\mathrm{d} 7$ to 11 with either insulin $\left(0.5 \mathrm{mU}\right.$ or $12.5 \mathrm{mU} \cdot \mathrm{g}^{-1}$ body wt) or saline. Values are mean $\pm \mathrm{SD}$. Compared to saline controls, the changes in plasma corticosterone of insulin-treated rats are not significant.
${ }^{14} \mathrm{C}$-leucine incorporated into BBM proteins, was equal in the two groups of animals. These data demonstrate that, after weaning, insulin had no effect on S-I synthesis rate and or on the amount of immunoreactive S-I protein present in the BBM. Similarly, after weaning, there was no effect of insulin treatment on the specific activity of $\mathrm{N}$-acetyl- $\beta$-glucosaminidase $(+8 \%$ versus controls), sulfatase C ( $-3.5 \%$ versus controls), or lactate dehydrogenase ( $+8 \%$ versus controls) (data not shown).

\section{DISCUSSION}

Our study confirms that insulin given to suckling rats accelerates the maturation of the enterocyte. Insulin given to 8-d-old pups induced the premature appearance of sucrase and caused significant increases in the activity of maltase, neutral lactase, and aminopeptidase. Insulin also decreased prematurely the activity of the lysosomal enzyme $\mathrm{N}$-acetyl- $\beta$-glucosaminidase, sulfatase $C$, and lactate dehydrogenase. When given at later ages (d 25 to 32) following the same experimental protocol, the hormone failed to affect BBM enzymes as well as lysosomal, microsomal, and cytosolic enzymes. Measurement of mature SI synthesis rate by the incorporation of ${ }^{14} \mathrm{C}$-leucine into the precursor protein was similar in insulin-treated rats and controls. Thus, the immature enterocyte of the suckling rat is responsive to insulin, whereas the mature enterocyte of the weaned rat is unresponsive.

Regarding the expression of intestinal enzymes in response to hormone administration, there is a striking parallelism between insulin and glucocorticoids. In the growing rat, Henning and coworkers $(23,24)$ have shown that intestinal BBM and lysosomal enzymes display glucocorticoid responsiveness from birth through $\mathrm{d} 17$ but not beyond this age. The enzymes studied (maltase, neutral lactase, and acid- $\beta$-galactosidase) lost their responsiveness to both exogenous glucocorticoid administration and adrenalectomy around the middle of the 3rd wk of life (17$18 \mathrm{~d}$ of age) $(23,24)$. The abrupt loss of glucocorticoid responsiveness applied to both the jejunum and the ileum, to both BBM and lysosomal enzymes, and to enzymes that show increasing activity during development, as well as to enzymes that show decreasing activity at weaning. Although we did not delineate exactly the age at which insulin responsiveness is lost, the present

Table 1. Sp act of intracellular enzymes in villus and crypt cells of suckling rats treated with insulin $\left(12.5 \mathrm{mU} \cdot \mathrm{g}^{-1}\right.$ body wt twice daily) or saline between 8 and 12 postpartum

\begin{tabular}{lccccccc}
\hline & \multicolumn{2}{c}{ Villus cells } & & \multicolumn{3}{c}{ Crypt cells } \\
\cline { 2 - 3 } & $\begin{array}{c}\text { Insulin } \\
(n=6)\end{array}$ & $\begin{array}{c}\text { Controls } \\
(n=6)\end{array}$ & & $p$ & $\begin{array}{c}\text { Insulin } \\
(n=6)\end{array}$ & $\begin{array}{c}\text { Controls } \\
(n=6)\end{array}$ & $p$ \\
\hline Sulfatase C & $0.069 \pm 0.027 \dagger$ & $0.129 \pm 0.005$ & $<0.01$ & & $0.071 \pm 0.022$ & $0.111 \pm 0.016$ & $<0.025$ \\
N-acetyl- $\beta$-glucosaminidase & $21.3 \pm 5.7$ & $43.2 \pm 16.2$ & $<0.025$ & $16.4 \pm 7.7$ & $38.6 \pm 14.4$ & $<0.05$ & NS \\
Lactate dehydrogenase & $44.9 \pm 22.1$ & $129 \pm 60.2$ & $<0.05$ & & $69.3 \pm 78.2$ & $158 \pm 74.2$ & NS
\end{tabular}

* One $U$ equals one $\mu \mathrm{mol}$ of substrate hydrolyzed per min per $\mathrm{g}$ cell protein.

$\dagger$ Values are mean $\pm \mathrm{SD}$.

Table 2. Sp act of BBM enzymes in suckling rats treated with insulin $\left(12.5 \mathrm{mU} \cdot \mathrm{g}^{-1}\right.$ body wt twice daily) or saline between $d 8$ and 12 postpartum

\begin{tabular}{|c|c|c|c|c|c|}
\hline & \multicolumn{4}{|c|}{ Enzyme activity* } & \multirow{2}{*}{$\begin{array}{c}\text { BBM protein } \\
\text { (mg/mL of } \mathrm{P} 2 \\
\text { purified fraction) }\end{array}$} \\
\hline & Lactase & Sucrase & Maltase & Aminopeptidase & \\
\hline Insulin $(n=6)$ & $516 \pm 44.2 \dagger$ & $9.73 \pm 5.11$ & $1097 \pm 142$ & $290 \pm 17.3$ & $2.77 \pm 0.51$ \\
\hline Controls $(n=6)$ & $395.9 \pm 69.5$ & NA $\ddagger$ & $474 \pm 64.6$ & $206 \pm 39.9$ & $2.95 \pm 0.51$ \\
\hline$\% \S$ & +30.4 & & +131 & +40 & -6.2 \\
\hline$p$ & $<0.01$ & $<0.001$ & $<0.001$ & $<0.01$ & NS \\
\hline
\end{tabular}

* Sp act ( $\mu$ mol of substrate hydrolyzed per min per $\mathrm{g}$ BBM protein).

$\dagger$ Values are mean \pm SD.

$\$$ No activity detected.

$\S$ Percent of increase versus controls. 
Table 3. Sp act of BBM enzymes in weaned rats treated with insulin $\left(12.5 \mathrm{mU} \cdot \mathrm{g}^{-1}\right.$ body wt, twice daily) or saline between $d 25$ and 32 postpartum

\begin{tabular}{|c|c|c|c|c|c|}
\hline & \multicolumn{4}{|c|}{ Enzyme activity* } & \multirow{2}{*}{$\begin{array}{c}\text { BBM protein } \\
(\mathrm{mg} / \mathrm{mL} \text { of } \mathrm{P} 2 \\
\text { purified fraction }\end{array}$} \\
\hline & Lactase & Sucrase & Maltase & Aminopeptidase & \\
\hline Insulin $(n=6)$ & $19.2 \pm 5.3 \dagger$ & $118.0 \pm 41.6$ & $1492 \pm 391$ & $590 \pm 102$ & $10.8 \pm 1.91$ \\
\hline Controls $(n=6)$ & $22.5 \pm 6.6$ & $104.9 \pm 20.3$ & $1406 \pm 183$ & $585 \pm 115$ & $10.5 \pm 1.83$ \\
\hline$\% \ddagger$ & -15 & +12.4 & +6.1 & +0.9 & +2.8 \\
\hline$p$ & NS & NS & NS & NS & NS \\
\hline
\end{tabular}

* Specific activity ( $\mu \mathrm{mol}$ of substrate hydrolyzed per min per g BBM protein).

+ Values are mean $\pm \mathrm{SD}$.

$\ddagger$ Changes in percent versus controls.

Table 4. Synthesis rate of immunoreactive BBM sucraseisomaltase $(S-I)$ in weaned rats $(32 d)$ treated with insulin $(12.5$

\begin{tabular}{lcc} 
& $m U \cdot g$ body wt) or saline \\
\hline & $\begin{array}{c}\text { Ratio of BBM } \\
\text { S-I protein } \\
\text { precipitated/total } \\
\text { BBM proteins }\end{array}$ & $\begin{array}{c}\text { cpm of }{ }^{14} \mathrm{C}-\text { leucine } \\
\text { into BBM S-I/ } \\
\text { cpm of } \\
\text { into BBM }{ }^{14} \mathrm{C}-\text { leucine }\end{array}$ \\
& $0.082 \pm 0.022^{*}$ & $0.039 \pm 0.014$ \\
Insulin $(n=6)$ & $0.088 \pm 0.024$ & $0.034 \pm 0.012$ \\
Controls $(n=6)$ & $\mathrm{NS}$ & $\mathrm{NS}$ \\
$p$ & &
\end{tabular}

$*$ Mean $\pm \mathrm{SD}$.

data suggest very similar conclusions. The parallelism between insulin and glucorticoid responsiveness according to age prompted us to clarify whether the exogenous administration of insulin to suckling rats is able to influence the endogenous production of corticosterone, the natural steroid of the rat. The data show that whatever the dose of insulin given ( 0.5 or 12.5 $\mathrm{mU}$ ), there is no significant rise in the plasma concentration of corticosterone compared to saline-treated controls. Furthermore, the mean levels of plasma corticosterone recorded in suckling animals (saline or insulin treated) remain far below the levels measured in weanling rats, which were about 9 -fold higher. Thus, the enzyme changes observed in response to insulin appear not to be mediated via endogenous stimulation of corticosterone release.

Further evidence for a direct action of insulin on the immature enterocyte is the findings that a single injection of a very low dose of insulin (devoid of any hypoglycemic reaction) to suckling pups elicits the premature appearance of sucrase activity in villus and crypt cells within $6 \mathrm{~h} \mathrm{(7),} \mathrm{and} \mathrm{that} \mathrm{the} \mathrm{addition} \mathrm{of} \mathrm{the}$ hormone to mouse jejunal explants maintained in serum-free organ culture reproduces the BBM enzyme changes observed in vivo (9).

Recently, it has been demonstrated in growing rats that the interaction of insulin with specific receptors on jejunoileal epithelial cells decreases with age (25). The concentration of insulin receptors was found to be high during the suckling period and to decrease markedly after weaning, whereas the circulating plasma levels of the hormone follow an inverse ontogenic pattern. Thus, the physiologic periods of "responsiveness" and of "unresponsiveness" to the hormone could be related in part to the binding capacity of the hormone to the intestinal cell, because in adult rat models of mucosal hyperplasia (lactation) and of hypoplasia (jejunoileal bypass) recent observations indicate that the receptor status plays a critical role in modulating the expression of BBM enzymes by the villus cell (26).

Taken as a whole, our data provide evidence that insulin is an important regulator involved in intestinal maturation.

Acknowledgments. The authors thank Lucien Erculisse for expert technical assistance and Dominique Vermeulen for preparation of the manuscript.

\section{REFERENCES}

1. Rubino A, Zimbalatti F, Auricchio $S 1964$ Intestinal disaccharidase activity in adult and suckling rats. Biochem Biophys Acta 92:305-311

2. Henning SJ 1981 Postnatal development: coordination of feeding digestion and metabolism. Am J Physiol 241:G199-G214

3. Yeh KY, Holt PR 1986 Ontogenic timing mechanism initiates the expression of rat intestinal sucrase activity. Gastroenterology 90:520-526

4. Doell RG, Kretchmer N 1964 Intestinal invertase: precocious development of activity after injection of hydrocortisone. Science 143:42-44

5. Koldovsky O, Jumawan J, Palmieri M 1975 Effect of thyroidectomy on the activity of $\alpha$-glucosidases and acid hydrolases in the small intestine of rats during weaning. J Endocrinol 66:31-36

6. Menard D, Malo C 1979 Insulin-evoked precocious appearance of intestinal sucrase activity in suckling mice. Dev Biol 69:661-665

7. Buts JP, De Keyser N, Dive C 1988 Intestinal development in the suckling rat: effect of insulin on the maturation of villus and crypt cell functions. Eur $J$ Clin Invest 18:391-398

8. Menard D, Malo C, Calvert R 1981 Insulin accelerates the development of intestinal brush border hydrolytic activities of suckling mice. Dev Biol $85: 150-155$

9. Arsenault P, Menard D 1984 Insulin influences the maturation and proliferation of suckling mouse intestinal mucosa in serum-free organ culture. Bio Neonate 46:229-236

10. Simon PM, Kedinger M, Raul F, Grenier JF, Haffen K 1982 The action of hormones on intestinal brush border enzymes in organ culture. In Vitro 18:339-346

11. Weiser MM 1973 Intestinal epithelial cell surface membrane glycoprotein synthesis. J Biol Chem 248:2536-2541

12. Raul F, Simon P, Kedinger M, Haffen K 1977 Intestinal enzyme activities in isolated villus and crypt cells during postnatal development of the rat. Cell Tissue Res 176:167-178

13. Schmitz J, Preiser H, Maestracci D, Ghosh BK, Cerda JJ, Crane RK 1973 Purification of the human intestinal brush border membrane. Biochem Biophys Acta 323:98-112

14. Buts JP, Vamecq J, Van Hoof F 1986 Alteration of intracellular synthesis of surface membrane glycoproteins in small intestine of iron-deficient rats. Am J Physiol 251:G736-G743

15. Kolanowski J 1974 Simultaneous determination of cortisol, deoxycortisol and corticosterone in plasma and urine by competitive protein binding assay. Response of normal subjects to ACTH and metyrapone. J Steroid Biochem 5:55-64

16. Dohler KD, Gartner K, Von zur Muhlen A, Dohler U 1977 Activation of anterior pituitary thyroid and adrenal glands in rats after disturbance stress. Acta Endocrinol 86:489-497

17. Messer M, Dahlqvist A 1966 A one step ultramicromethod for the assay of intestinal disaccharidases. Anal Biochem 14:376-392

18. Maroux S, Louvard D, Baratti J 1973 The aminopeptidase from the hog intestinal brush border. Anal Biochem 14:376-392

19. Lowry OH, Rosebrough NJ, Farr AL, Randall RJ 1951 Protein measurement with the folin phenol reagent. J Biol Chem 193:265-275

20. Van Hoof F, Hers HG 1968 The abnormalities of lysosomal enzymes in mucopolysaccharidoses. Eur J Biochem 7:34-44

21. Vassault A 1983 Lactate dehydrogenase. UV method with pyruvate and NADH in methods of enzymatic. In: Bergmeyer HU, (ed), Analysis, vol 3, 3rd Ed Verlag Chemie, Weinheim, pp 118-126

22. Koldovsky O, Palmieri M 1971 Cortisone-evoked decrease of acid $\beta$-galactosidase, $\beta$-glucuronidase, $\mathrm{N}$-acetyl- $\beta$-glucosaminidase and arylsulphatase in the ileum of suckling rats. Biochem J 125:697-701

23. Henning SJ, Sims JM 1979 Delineation of the glucocorticoid sensitive period of intestinal development in the rat. Endocrinology 104:1158-1163

24. Henning SJ, Leeper LL 1982 Coordinate loss of glucorticoid responsiveness by intestinal enzymes during postnatal development. Am J Physiol 242:G89G94

25. Fernandes-Moreno MD, Fernandez-Gonzalez MA, Diaz-Juarez JL, LopezLuna MP, Prieto JC 1988 Interaction of insulin with small intestinal epithelial cells from developing rats. Biol Neonate 54:289-293

26. Young CP, Morton CL, Rose IS, Taranto TM, Bhathal PS 1987 Effects of intestinal adaptation on insulin binding to villus cell membranes Gut 28:5762 